\title{
Superoxide Production by Ciliated Epithelial Cells in the Respiratory Tract of Chicks
}

\author{
Yasuhiro KONDO, Setsuo MORIWAKI ${ }^{1)}$ \\ and Asaki ABE \\ Faculty of Agriculture, Okayama University, Okayama-shi 700-8530 \\ 1) National Livestock Breeding Center Okazaki Farm, Okazaki-shi 444-3161
}

(Received July 6, 1998)

\begin{abstract}
In the present study, we examined superoxide production by zymosan-and PMAstimulated ciliated epithelium of the respiratory tract in chicks by direct observation of reduced nitroblue tetrazolium (NBT) in the cytoplasm of each cell. The majority of the ciliated epithelial cells showed negative staining in cytoplasmic reduced NBT. However, a minor fraction of cells were positive in cytoplasmic reduced NBT. The present results suggested that ciliated epithelial cells of the chicken respiratory tract can possibly contribute to bactericidal function in the respiratory organ of chickens, although only a part of cells were active in superoxide production.

Anim. Sci. Technol. (Jpn.) 69 (12) : 1099-1101, 1998

Key words : Superoxide production, Respiratory ciliated epithelium, Chick
\end{abstract}

Active oxygens, such as superoxide, produced by leucocytes play an essential role in bactericidal function. Superoxide production has been determined in each of the macrophages and neutrophils by observation of reduced nitroblue tetrazolium (NBT) staining in the cytoplasm ${ }^{4}$. Human and bovine endothelial cells have been reported to show phagocytic activities and to produce superoxide and $\mathrm{H}_{2} \mathrm{O}_{2}$ by bacterial or phorbol stimulation $^{2.7)}$. In the present study, we examined the superoxide production in each ciliated epithelial cell collected from the respiratory tract of chicks by staining of reduced NBT diformazan in the cytoplasm.

\section{Materials and Methods}

\section{Collection of cells}

Ten male chicks of the White Leghorn Shaver Strain, 7 to 8 weeks old, were used. A silicone tube $(2 \mathrm{~mm}$ inner diameter, about $10 \mathrm{~cm}$ long) was inserted into the trachea cut 1 to $2 \mathrm{~cm}$ below the laryngeal aperture in chick after the animal was killed by exsanguination. Ten $\mathrm{m} l$ of $\mathrm{Mg}, \mathrm{Ca}(-)$ Hanks' balanced salt solution containing $0.05 \%$ EDTA (HBSS) per $100 \mathrm{~g}$ of body weight was injected through the tube. The injection fluid was drawn up and passed repeatedly through a $30 \mathrm{~m} l$ plastic syringe, then recovered. The cells recovered from the fluid were washed twice with HBSS, and then resuspended in HEPES-RPMI 1640 culture medium. The recovered cells consisted of a

ヒナの気道線毛上皮細胞によるスーパーオキサイド産生 : 近藤康博・森脇節夫”・阿部浅樹（岡山大学農学部，岡 山市 700-8530， 1) 農林水産省家畜改良せンター岡崎牧場, 岡崎市 444-3161)

Anim. Sci. Technol. (Jpn.) 69 (12) : 1099-1101 1099 


\section{KONDO, MORIWAKI and ABE}

large number of alveolar macrophages and a small number of ciliated epithelial cells from the respiratory tract (below 1\%, 100 to 200 cells/chick).

\section{Superoxide production assay}

Cells recovered as described were treated with opsonized zymosan A (Sigma) or phorbol myristate acetate (PMA, Sigma), and then NBT, freshly prepared chicken serum and $0.01 \mathrm{M}$ KCN were added as reported previously). The mixture was incubated in a shaking water bath for $60 \mathrm{~min}$ at $39^{\circ} \mathrm{C}$. After incubation, superoxide production was determined by the presence of dark blue NBT diformazan in the cytoplasm of ciliated epithelium under a microscope $(\times 40)$ as previously reported in white blood cells ${ }^{4}$. Density of NBT diformazan in the cytoplasm of each cell was determined by subjective visual evaluation under a microscope.

\section{Results and Discussion}

The majority (80 to $90 \%$ ) of zymosan- or PMA-stimulated ciliated epithelial cells in the respiratory tract did not have capacity to reduce NBT, that is, did not produce superoxide, as estimated by visual inspection of the cytoplasm (Table 1). However, the minor fraction of the cells showed positive cytoplasmic staining of dark blue, indicating a reduced NBT (Fig. 1). Density of the reduced NBT in the positive cells were classified into three classes (weak, medium and strong, Table 1). The percentage of cells which showed weak density $(6.9 \%$ in zymosan- stimulated cells and $13.3 \%$ in PMA-stimulated cells) was the highest among the three classes. The incidences of cells showing medium and strong density of reduced NBT were low in the cells stimulated with both stimulators. These results suggest that a minor part of ciliated epithelium of the chicken repiratory tract are able to produce superoxide in the presence of stimulators and the ciliated epithelium can be classified into several types based on superoxide production.

Table 1. Percentages of cells classified by visual inspection of reduced nitroblue tetrazolium (NBT) in the cytoplasm of ciliated epithelial cells in the respiratory tract of chicks

\begin{tabular}{lcccc}
\hline \hline \multirow{2}{*}{ Stimulator } & \multicolumn{3}{c}{$\begin{array}{l}\text { Percentages of cells classified by visual } \\
\text { inspection of reduced NBT (Mean } \pm \text { SE) }\end{array}$} \\
\cline { 2 - 6 } & None & Weak & Medium & Strong \\
\hline Zymosan & $90.0 \pm 2.3$ & $6.9 \pm 1.3$ & $2.0 \pm 0.4$ & $1.0 \pm 0.1$ \\
PMA $^{*}$ & $81.3 \pm 5.4$ & $13.3 \pm 2.4$ & $4.0 \pm 0.9$ & $1.3 \pm 1.0$ \\
\hline
\end{tabular}

* PMA : phorbol myristate acetate.

A

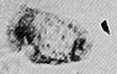

B

Fig. 1. Ciliated epithelial cells showed reduced NBT in the cytoplasm in the respiratory tract of chicks. A and B : representatively showed medium and strong density of cytoplasmic reduced NBT, respectively.

This is similar to zymosan- or PMAstimulated alveolar macrophages of chicks which may also be classified into several types by the level of superoxide production (unpublished data). It is well documented that superoxide produced by several phagocytes $^{1,3,4)}$ is essential to bactericidal activity for microorganisms ingested in phagocytes. Cells other than phagocytes, namely, human endothelial cells have been reported to release active oxygens such as superoxide when cultured with stimulators such as polystyrene particles or $\mathrm{PMA}^{2}$. Significance of superoxide production by ciliated epithelium is unclear at present time. However, it is possible to assume that superoxide produced by ciliated epithelium is contributed to bactericidal mechanism in the respiratory tract of chicken. Conjunctival ${ }^{8)}$, intestinal ${ }^{5)}$ and gingival epithelial cells ${ }^{6)}$ have been reported to phagocytoze bacterias or latex beads. These results suggest that some kinds of epithelial cells 
contribute to defense mechanisms in the outer and inner surfaces of animal bodies. It is interesting to research whether ciliated epithelium of the chicken respiratory tract have phagocytic activity or not.

\section{References}

1) Babior BM, Kipnes RS, Curnutte JT. The production by leukocytes of superoxide, a potential bactericidal agent. J. Clin. Invest., 52 : 741744. 1973.

2) Gorog P, Pearson JD, Kakkar W. Generation of reactive oxygen metabolites by phagocytosing endothelial cells. Atherosclerosis, $72: 19-$ 27. 1988.

3) Kondo $Y$. Effects of starvation on nitrobluetetrazolium reducing activity and myeroperoxidase level in heterophils of chicks. Jpn. Poult. Sci., $30: 371-376$. 1993. (In
Japanese)

4) Lowrie DB, Aber VR. Superoxide production by rabbit pulmonary alveolar macrophages. Life Sci., 21 : 1575-1584. 1977.

5) Mapother ME, Songer JG. In vitro interaction of mycobacterium avium with intestinal epithelial cells. Infect. Immun., $45: 67-73.1984$.

6) Pinero $G J$, White RR. Phagocytosis of latex beads by human gingival epithelial-like cell line in tissue. J. Dent. Res., 56 : 1119-26. 1977.

7) Ryan US, Schltz DR, Goodwin JD, Vann JM, Selvaraj MP, Hart MA. Role of $\mathrm{Clq}$ in pahgocytosis of salmonella minnesota by pulmonary endothelial cells. Infect. Immun., 57 : 1156-1362. 1989.

8) Zimianski MC, Dawson CR, Tongi B. Epithelial cell phagocytosis of listeria monocytogenes in the conjunctiva. Invest. Opthalmol., 13:623626. 1974. 